\title{
Erratum to: Mass Flow through Solid ${ }^{4} \mathrm{He}$
}

\author{
M.W. Ray • R.B. Hallock
}

Published online: 16 October 2009

(C) Springer Science+Business Media, LLC 2009

\section{Erratum to: J Low Temp Phys DOI 10.1007/s10909-009-9975-y}

There is a typo in title of the original paper. The publisher regrets the error. The correct article title is as follows:

\section{Mass Flow through Solid ${ }^{4} \mathrm{He}$}

The online version of the original article can be found under doi:10.1007/s10909-009-9975-y.

M.W. Ray $(\bowtie) \cdot$ R.B. Hallock

Laboratory for Low Temperature Physics, Department of Physics, University of Massachusetts, Amherst, MA 01003, USA

e-mail: mray@physics.umass.edu

R.B. Hallock

e-mail: hallock@physics.umass.edu 